\title{
Deskripsi Sikap Kemandirian Siswa terhadap Mata Pelajaran IPA Pada Materi Pesawat Sederhana
}

\author{
Rahma Julia Hastirani ${ }^{1}$, Nurhafizah ${ }^{2}$ \\ ${ }^{1}$ Pendidikan Fisika, FKIP, Universitas Jambi \\ ${ }^{2}$ SMPN 2, Tanjab Barat, Jambi \\ Juliahastiranirahma@gmail.com
}

\begin{abstract}
ABSTRAK
Tujuan dari penelitian ini adalah untuk menganalisis gambaran sikap kemandirian terhadap mata pelajaran IPA, yaitu fisika pada materi pesawat sederhana. Pendekatan yang digunakan dalam penelitian ini adalah pendekatan kualitatif dengan metode deskriptif. Penelitian ini menggunakan teknik pengambilan sampel, yaitu total sampling. Hal yang diamati dalam penelitian ini adalah sikap kemandirian siswa kelas VIII SMPN 09 Muaro Jambi terhadap mata pelajaran IPA. Instrumen yang digunakan pada penelitian ini ialah lembar observasi berupa angket karakter kemandirian terhadap mata pelajaran IPA yang sudah di validasi oleh validator ahli. Angket sikap ini dilakukan dengan menggunakan pengukuran skala likert. Penilaian skala likert adalah sangat setuju (SS), setuju (S), tidak setuju (TS), dan sangat tidak setuju (STS). Hasil penelitian yang dilakukan mengenai sikap kemandirian siswa terhadap mata pelajaran IPA di SMPN 09 Muaro Jambi. Deskripsi sikap kemandirian siswa berada pada kategori sangat baik. Dilihat dari statistik deskriptif mulai dari mean, modus, median, skor minimum dan skor maksimum yang telah dilihat dan dibandingkan dari dua kelas yang berbeda yaitu kelas VIII B dan VIII C dengan jumlah siswa 53 orang.
\end{abstract}

Kata kunci: Sikap Kemandirian, Materi Pesawat Sederhana

\section{ABSTRACT}

The purpose of this study was to analyze the description of the attitude of independence towards natural science subjects, namely physics in simple aircraft matter. The approach used in this study is a qualitative approach with descriptive methods. This study uses sampling techniques, namely total sampling. The thing observed in this study is the attitude of the independence of class VIII Muaro Jambi SMPN 09 towards science subjects. The instrument used in this study is the observation sheet in the form of a character questionnaire of independence for science subjects that have been validated by expert validators. This attitude questionnaire is done using the Likert scale measurement. Likert scale assessments are strongly agree (SS), agree (S), disagree (TS), and strongly disagree (STS). The results of the research were conducted on the attitude of students' independence towards science subjects at Muaro Jambi Middle School 09. The description of students' independence attitude is in a very good category. Viewed from descriptive statistics starting from the mean, mode, median, minimum score and maximum score that has been seen and compared from two different classes namely class VIII B and VIII C with a total of 53 students.

Keywords: attitude of independence, simple aircraft matter

\section{PENDAHULUAN}

Kegiatan pendidikan adalah banyak cakupannya dan sangat berkaitan dengan perkembangan manusia muda, mulai perkembangan jasmaniah dan rohaniah, antara lain : perkembangan fisik, pikiran, perasaan, kemauan, kesehatan, keterampilan, sosial, hati nurani dan kasih sayang (Amus dan Grace, 2017). Pendidikan menurut UU No.20 tahun 2003 adalah sebuah usaha yang dilakukan secara sadar dan terencana untuk mewujudkan suasana belajar dan proses pembelajaran agar peserta didik secara aktif mengembangkan potensi diri nya untuk memiliki kekuatan spritual keagamaan, membangun kepribadian, pengendalian diri, kecerdasan, akhlak mulia, serta keterampilan diperlukan dirinya, masyarakat, bangsa dan negara (Republik 
Indonesia, 2003). Pendidikan itu sendiri mempunyai tujuan untuk mengembangkan potensi yang terdapat pada peserta didik, agar dapat berpikir secara kritis maupun kreatif (Sisdiknas,2003). Dalam pendidikan di Indonesia sendiri terdapat beberapa tingkatan, salah satu nya tingkat sekolah menengah pertama, sekolah menengah pertama merupakan tingkat pendidikan yang wajib di tempuh, sebelum melanjutkan ke tahap pendidikan selanjutnya ke tingkatan yang lebih tinggi. Dalam tingkatan pendidikan sekolah menegah pertama, mempelajari berbagai ilmu pengetahuan salah satu nya yang dipelajari ialah IPA atau Ilmu Fisika. Fisika merupakan salah satu ilmu yang berkembang dari pengamatan gejala alam dan interaksi yang terjadi di dalam nya (Asih, 2017). Selain itu fisika merupakan ilmu sains yang berintegrasi dengan perilaku dan gejala-gejala fenomena alam yang dikaitkan dengan fenomena sekarang atau yang terjadi saat ini (Giancoli, 2014).

Mata pelajaran fisika dapat di kategorikan sebagai mata pelajaran yang kurang di sukai oleh peserta didik. Peserta didik menganggap fisika sebagai subjek yang sulit selama masa sekolah dan semakin sulit lagi ketika mereka mencapai pada sekolah menengah atas (Guido, 2013). Dalam proses pembelajaran, khususnya dalam pelajaran fisika, sikap peserta didik sangatlah penting. Sikap yang berlangsung selama terjadi nya proses pembelajaran sangat penting dalam mengarahkan perilaku manusia (Kaya, 2011). Karena peserta didik yang memiliki pandangan tersebut sikap nya akan berbeda dengan peserta didik yang memiliki pandangan lebih positif selama proses pembelajaran (Arsaythamby Veloo, 2015). Oleh karena itu, untuk peserta didik yang memiliki sikap positif dalam pembelajaran akan mempengaruhi atau meningkatkan hasil belajar dari peserta didik tersebut.

Salah satu masalah bagi pengajar adalah bahwa kesulitan dalam mengukur sikap. Tentu sikap adalah di bentuk dan di ubah selama dalam pendidikan atau pelatihan (Abbat, 1998). Sikap itu berasal dari dalam diri peserta didik itu sendiri, yaitu perasaan terhadap suatu objek yang di perlihatkan dalam perasaan suka ataupun tidak suka. Hal ini sesuai dengan (Nursa'adah, 2016) bahwa sikap merupakan tingkah laku atau perbuatan akibat reaksi seseorang terhadap orang lain atau benda tertentu. Peserta didik yang tidak menyukai fisika dapat dilihat dari sikap dan hasil belajar nya terhadap fisika (Erdemir, 2009). Kurang nya sikap positif yang dimiliki peserta didik, terhadap pelajaran fisika mengakibatkan berbagai masalah. Peserta didik yang memiliki sikap negatif terhadap fisika akan mengurangi tingkat kepercayaan dirinya dan membuat hasil kinerja buruk yang disebabkan kurang nya mencari informasi untuk menyelesaikan masalah fisika (Olosimbo, 2012). Sikap positif peserta didik terhadap mata pelajaran fisika terintegrasi dengan implikasi sosial dari fisika, sikap ilmiah, kesenangan belajar fisika dan sikap kemandirian dalam pembelajaran. Implikasi sosial dari fisika menunjukkan bagaimana pengaruh atau dampak dari ilmu fisika terhadap kehidupan sosial. Ini dapat berupa sikap terhadap manfaat sosial dan masalah kemajuan dan penelitian ilmiah (Welch, 2010). Dalam pembelajaran di sekolah ketika di dalam kelas, kita dapat menemukan implikasi sosial dari fisika, yaitu kerjasama dan kemandirian peserta didik tersebut dalam kelompok belajarnya (Burke, 2011).

Sikap kemandirian pada siswa sangat penting apalagi dalam pembelajaran, itu akan sangat memudahkan para guru dalam pengajaran yang membuat siswa tertarik untuk belajar sendiri, mencari-cari sumber referensi yang tidak hanya dari guru tersebut. Banyak cara yang bisa dilakukan dalam sikap kemandirian siswa tersebut. Kemandirian merupakan sikap individu yang diperoleh secara kumulatif selama perkembangan, individu akan terus belajar untuk bersikap mandiri dalam menghadapi berbagai situasi di lingkungan, sehingga individu pada akhirnya akan mampu berpikir dan bertindak keras dengan pertimbangan diri sendiri dan orang lain. Dengan kemandiriannya seseorang dapat 
memilih jalan hidupnya untuk dapat berkembang dengan lebih mantap (Susanto, 2018). Kemandirian sebagai kekuatan motivasional dalam diri individu untuk mengambil keputusan dan menerima tanggung jawab atas konsekuensi keputusan ini. Kesempatan untuk mengawali, menjaga dan mengatur tingkah laku menunjukkan adanya suatu kebebasan pada individu yang mandiri untuk menentukan sendiri perilaku yang hendak ia tampilkan, menentukan langkah hidupnya, tujuan hidupnya dan nilai-nilai yang di anut (Kartadina, 1988). Kemandirian merupakan salah satu aspek penting penunjang keberhasilan siswa mencapai masa depan, karena dengan mandiri siswa itu tidak akan terus bergantung pada orang lain. Namun tidak semua siswa bisa berlaku mandiri dengan sendiri nya. Dengan kemandirian tersebut siswa akan terhindar dari sifat ketergantungan pada orang lain dan yang paling penting adalah menumbuhkan keberanian dan motivasi pada siswa untuk terus mengekspresikan pengetahuan goreng ketahuan baru. Untuk itu, kita perlu kiranya mengetahui dan memahami apa yang dapat mempengaruhi kemandirian siswa serta bagaimana upaya yang dapat kita lakukan untuk mengembangkan kemandirian siswa (Ni'matuzahroh, 2018). Singkatnya kemandirian adalah suatu kemampuan untuk mengatur diri sendiri.

Tujuan dari penelitian ini adalah untuk menganalisis gambaran sikap kemandirian terhadap mata pelajaran IPA, yaitu fisika pada materi pesawat sederhana.

\section{METODE PENELITIAN}

Pendekatan yang digunakan dalam penelitian ini adalah pendekatan kualitatif dengan metode deskriptif. Penelitian dilaksanakan di SMPN 09 Muaro Jambi, Kb.IX Sungai Gelam, Kabupaten Muaro
Jambi. Populasi penelitian yang diambil ialah siswa SMPN 09 Muaro Jambi yang dengan mata pelajaran IPA fisika materi pesawat sederhana. Sampel penelitian ini ialah 2 kelas yaitu kelas VIII B dan VIII C yang berjumlah 53 orang. Penelitian ini menggunakan teknik pengambilan sampel, yaitu total sampling. Hal yang diamati dalam penelitian ini adalah sikap kemandirian siswa kelas VIII SMPN 09 Muaro Jambi terhadap mata pelajaran IPA. Instrumen yang digunakan pada penelitian ini ialah lembar observasi berupa angket karakter kemandirian terhadap mata pelajaran IPA yang sudah di validasi oleh validator ahli. Angket sikap ini dilakukan dengan menggunakan pengukuran skala likert. Penilaian skala likert adalah sangat setuju (SS), setuju (S), tidak setuju (TS), dan sangat tidak setuju (STS). Untuk pernyataan yang bernilai positif (+) pengukuran dimulai dari nilai 4 , 3, 2, dan 1 pada skala sangat setuju (SS). Sedangkan untuk pernyataan yang bernilai negatif (-) pengukurannya dimulai dari nilai 4, 3, 2, dan 1 pada skala sangat tidak setuju (STS). Penelitian ini menggunakan 1 analisis. Analisis data angket sikap kemandirian siswa terhadap mata pelajaran IPA dengan menggunakan statistik deskriptif yaitu menghitung mean, modus, median dan standar deviasi. "Statistik Deskriptif adalah statistik yang digunakan untuk menganalisis data dengan cara mendeskripsikan atau menggambarkan data yang telah terkumpul sebagaimana adanya tanpa bermaksud membuat kesimpulan yang berlaku untuk umum atau generalisasi (Sugiyono, 2016).

\section{HASIL \& PEMBAHASAN}

Hasil pengolahan data angket kemandirian siswa SMP terhadap mata pelajaran IPA dapat di deskripsikan oleh tabel berikut :

Tabel 1.

Statistik Deskriptif angket kemandirian siswa kelas VIII B dari IPA SMPN 09 Muaro Jambi

\begin{tabular}{ll}
\hline Mean & 81,7778 \\
\hline Median & 82 \\
\hline Modus & 81 \\
\hline
\end{tabular}




\begin{tabular}{ll}
\hline Standar Deviasi & 3,19 \\
\hline Range & 17 \\
\hline Skor minimum & 71 \\
\hline Skor maksimum & 88 \\
\hline
\end{tabular}

Statistik Deskriptif angket kemandirian siswa kelas VIII C dari IPA SMPN 09 Muaro Jambi

\begin{tabular}{ll}
\hline Mean & 82,5 \\
\hline Median & 82 \\
\hline Modus & 78 \\
\hline Standar Deviasi & 3,82 \\
\hline Range & 14 \\
\hline Skor minimum & 77 \\
\hline Skor maksimum & 91 \\
\hline
\end{tabular}

Deskripsi hasil dari sikap kemandirian siswa kelas VIII B maupun VIII C SMPN 09 Muaro Jambi terhadapa mata pelajaran IPA pada materi pesawat sederhana pada tabel 1 dan 2 di ukur dari pengolahan data statistik deskriptif yaitu dari Mean, Modus, Median, Standar Deviasi, Range, skor minimum dan skor maksimum nya. Pentingnya kemandirian terhadap mata pelajaran IPA bagi siswa, dimana kemandirian merupakan salah satu aspek penting penunjang keberhasilan siswa mencapai masa depan, karena dengan mandiri siswa itu tidak akan terus bergantung pada orang lain. Namun tidak semua siswa bisa berlaku mandiri dengan sendiri nya. Dengan kemandirian tersebut siswa akan terhindar dari sifat ketergantungan pada orang lain dan yang paling penting adalah menumbuhkan keberanian dan motivasi pada siswa untuk terus mengekspresikan pengetahuan goreng ketahuan baru. Untuk itu, kita perlu kiranya mengetahui dan memahami apa yang dapat mempengaruhi kemandirian siswa serta bagaimana upaya yang dapat kita lakukan untuk mengembangkan kemandirian siswa (Ni'matuzahroh, 2018). Hasil penelitian terlihat bahwa hasil sikap kemandirian siswa perindikator bervariasi dari kategori sangat tidak baik, tidak baik, baik, dan sangat baik.

Pada statistik deskriptif yang telah di dapat pada tabel 1 dan 2 yaitu dari Mean, Modus, Median, skor minimum dan skor maksimum. Dan disini saya akan melihat atau membandingkan dari dua kelas yang berbeda dari kelas VIII B dan VIII C di ukur dari tingkat sikap kemandiriannya terhadap pelajaran IPA. Nah dapat dilihat dari tabel tersebut hasilnya. Pada tabel 1 di dapat mean nya adalah 81,7 dan pada tabel 2 mean nya adalah 82,5 dari kedua nya dapat dilihat bahwa kelas VIII C lebih baik. Selanjutnya median pada tabel 1 adalah 82 dan pada tabel 2 adalah 82 dapat dilihat antara kelas VIII B dan VIII C memiliki keseimbangan dilihat daru nilai median nya. Selanjutnya modus pada tabel 1 adalah 81 dan pada tabel 2 adalah 78 jadi dapat kita lihat bahwa kelas VIII B lebih baik daripada VIII C karena nilai yang paling banyak muncul nya lebih tinggi. Selanjutnya skor minimum pada tabel 1 adalah 71 dan pada tabel 2 adalah 77 jadi bisa kita katakan bahwa kelas VIII C lebih baik karena memiliki nilai minimum lebih tinggi daripada VIII B. Selanjutnya skor maksimum pada tabel 1 adalah 88 dan pada tabel 2 adalah 91 dapat dilihat bahwa kelas VIII $\mathrm{C}$ lebih baik karena memiliki nilai maksimum lebih tinggi daripada kelas VIII B. Jadi dapat disimpulkan dari data yang telah ada bahwa siswa SMPN 09 Muaro Jambu kelas VIII C lebih baik pada tingkat sikap kemandiriannya daripada kelas VIII B. Tapi jika disimpulkan secara umum bahwa siswa kelas VIII B dan VIII C SMPN 09 Muaro Jambi memiliki tingkat kemandirian yg sangat baik dari jumlah 
keseluruhan siswa kelas VIII B dan VIII C yaitu 53 orang siswa tersebut.

$\begin{array}{llr} & \text { Sikap kemandirian pada } & \text { siswa } \\ \text { sangat penting apalagi } & \text { dalam } \\ \text { pembelajaran, itu akan } & \text { sangat }\end{array}$
memudahkan para guru dalam pengajaran yang membuat siswa tertarik untuk belajar sendiri, mencari-cari sumber referensi yang tidak hanya dari guru tersebut. Banyak cara yang bisa dilakukan dalam sikap kemandirian siswa tersebut. Kemandirian merupakan sikap individu yang diperoleh secara kumulatif selama perkembangan, individu akan terus belajar untuk bersikap mandiri dalam menghadapi berbagai situasi di lingkungan, sehingga individu pada akhirnya akan mampu berpikir dan bertindak keras dengan pertimbangan diri sendiri dan orang lain. Dengan kemandiriannya seseorang dapat memilih jalan hidupnya untuk dapat

\section{KESIMPULAN \& SARAN}

Berdasarkan hasil penelitian yang dilakukan mengenai sikap kemandirian siswa terhadap mata pelajaran IPA di SMPN 09 Muaro Jambi. Deskripsi sikap kemandirian siswa berada pada kategori sangat baik. Dilihat dari statistik deskriptif mulai dari mean, modus, median, skor minimum dan skor maksimum yang telah dilihat dan dibandingkan dari dua kelas yang berbeda yaitu kelas VIII B dan VIII C dengan jumlah siswa 53 orang.

Penemuan pada penelitian ini di harapkan dapat memberikan kontribusi untuk sikap kemandirian siswa SMP terhadap mata pelajaran IPA terutama du kabupaten Muaro Jambi akan semakin meningkat. Dab diharapkan nanti nya dengan meningkat nya sikap kemandirian siswa SMP terhadap mata pelajaran IPA di kabupaten Muaro Jambi dapat bersaing untuk menjadikan pendidikan yang lebih baik dan dapat menjadikan contoh bagi sekolah lain dalam memotivasi pendidikan yang ada di Indonesia. Pentingnya guru untuk mengetahui sikap kemandirian siswa SMP terhadap mata pelajaran IPA di sadari oleh adanya sikpa menerima ataupun menolak dalam proses pembelajaran dan berkembang dengan lebih mantap (Susanto, 2018). Kemandirian sebagai kekuatan motivasional dalam diri individu untuk mengambil keputusan dan menerima tanggung jawab atas konsekuensi keputusan ini. Kesempatan untuk mengawali, menjaga dan mengatur tingkah laku menunjukkan adanya suatu kebebasan pada individu yang mandiri untuk menentukan sendiri perilaku yang hendak ia tampilkan, menentukan langkah hidupnya, tujuan hidupnya dan nilai-nilai yang di anut (Kartadina, 1988). Singkat nya kemandirian adalah suatu kemampuan untuk mengatur diri sendiri.

Jadi inti dari semua nya bahwa sikap kemandirian pada siswa sangat penting dan harus di miliki dari setiap siswa karena itu akan sangat bermanfaat nanti nya bagi siswa tersebut.

agar membuat siswa lebih cekatan dan kreatif dengan kemandiriannya yang di miliki dalam mengatasi atau memecahkan masalah dalam pembelajaran terutama pada mata pelajaran IPA. Dan biasanya hal tersebut akan terlihat dari tingkah laku maupun perilaku ataupun sikap siswa saat guru menjelaskan materi pelajaran IPA saat proses pembelajaran ataupun di luar itu. Untuk menghindari hal tersebut guru sebaiknya merancang pembelajaran dengan kreatif dan di sesuaikan dengan kondisi siswa agar bisa tercipta sikap kemandirian siswa terhadap mata pelajaran IPA tersebut. Design pembelajaran yang dibuat agar dapat menjadikan siswa belajar lebih dalam dengan rasa ingin tahu yang cukup tinggi dan siswa akan mencari tau dengan kemandirian siswa tersebut. Dan meningkatkan kemampuan berpikir secara kritis terhadap mata pelajaran IPA. Salah satu design pembelajaran yang mampu meningkatkan kemandirian berfikir dan belajar siswa adalah dengan membuat kelompok 1 atau 2 orang perkelompok yang memicu rasa ingin tau siswa dengan kemandirian siswa dalam mencari atau memecahkan masalah yang ada tersebut. 


\section{DAFTAR PUSTAKA}

Abbath, 1998. Pengajaran yang Efektif. Jakarta : Buku Kedokteran.

Arsaythamby Veloo, R. N. (2015). Attitude towards Physics and Additional Mathematics Achievement towards Physics Achievement. International Education Studies, 35-43.

Ahmad Arifin. 2014. Pengaruh Lingkungan Keluarga dan Kemandirian Belajar Terhadap prestasi belajar siswa kelas XI program studi Teknik Video di SMK Muhammadyah 1 Bantul. Yogyakarta : UNY.(Skripsi)

Asih, D, A, P. (2017). Pengaruh Pengguna Fasilitas Belajar di Lingkungan Alam Sekitar Terhadap Keterampilan Proses Sains. Jurnal Formatif, 7(1): 13-21.

Astalini, dkk. 2018. Sikap terhadap Mata Pelajaran IPA di SMP se-Kabupaten Muaro Jambi. Vol 21.No.2. ISSN : 214227.

Astalini, dkk. 2019. Identifikasi Sikap Peserta Didik Terhadap Mata Pelajaran Fisika Di Sekolah Menengah Atas Negri 5 Kota Jambi. ISSN : 2252-6935.

Astalini, dkk. 2018. Sikap Siswa Terhadap Pelajaran Fisika di SMAN kabupaten Batanghari. Vol.3 No.2. ISSN : 24775959.

Burke, Alison. 2011. Group Work: How to Use Groups Effectively. The Journal of Effective Teaching, Vol. 11, No. 2, 2011, hal 87-95.

Darmadji, dkk. 2018. Deskripsi Keterampilan proses sains Mahasiswa pada Materi Termodinamika. Vol.6 No.3. ISSN : 2337-604X.

Depdiknas .2003. Undang-undang RI No.20 tahun 2003. Tentang sistem pendidikan nasional.

Erdemir, N. (2009). Determining students' attitude towards physics through problemsolving strategy. Asia-Pacific Forum on Science Learning and Teaching, 1-19.

Guido, R. M. (2013). Attitude and Motivation towards Learning Physics. International Journal of Engineering Research \& Technology , 2087-2094.

Giancoli, D. C. (2014). Fisika : Prinsip dan Aplikasi Edisi ke 7Jilid 1. Jakarta: Erlangga.

Kartadina, 1988. Teknik pengukuran dan penilaian hasil belajar. Bandung : Rosda.

Kaya, H. \&. (2011). Attitude towards Physics Lessons and Physical Experiments of the
High School Students. European journal of physics education, 23-31.

Neolaha, Amus dan A. grace. 2017. Landasan Pendidikan : Dasar pengenalan diri sendiri menuju perubahan hidup. Jakarta : Kencana.

Nursa'adah, F, P \& Rosa, N, M. (2016). Analisis kemampuan Berpikir Kreatif Kimia Ditinjau dari Adversity Quotient, Sikap Ilmiah dan Minat Belajar. Jurnal Formatif, 6(3): 197-206.

Olasimbo, O. a. (2012). Attitudes of Students towards the Study of Physics in College of Education Ikere Ekiti, Ekiti State, Nigeria . American International Journal of Contemporary Research, 86-89.

Prasetya,s dan Ni'matuzahroh.2018. Observasi : Teori dan Aplikasi dalam psikologi. Malang : UNM.

Republik Indonesia. Undang-Undang RI Nomor 20 Tahun 2003 tentang Sistem Pendidikan Nasional (2003). Jakarta: Sekretariat Negara.

Sugiyono. (2016). Metode Penelitian Kuantitatif, Kualitatif, dan R\&D. Bandung: Alfabeta

Susanti, A. 2018. Bimbingan dan Konseling di sekolah Konsep, teori dan aplikasinya. Jakarta : Prenadamedia Group.

Welch, A. G. (2010). Using the TOSRA to Assess High School Students' Attitudes toward Science after Competing In the FIRST Robotics Competition: An Exploratory Stud. Eurasia Journal of Mathematics, Science \& Technology Education, 187-197. 